\title{
Homeopathy in the Rust Severity and Growth of Malva sylvestris L.
}

\author{
Leyza Paloschi de Oliveira ${ }^{1}$, Simone Silmara Werner ${ }^{2}$, Mari Inês Carissimi Boff ${ }^{1} \&$ Pedro Boff $^{2}$ \\ ${ }^{1}$ Centro de Ciências Agroveterinárias, Universidade do Estado de Santa Catarina, Lages, Brazil \\ ${ }^{2}$ Empresa de Pesquisa Agropecuária e Extensão Rural de Santa Catarina, Lages, Brazil \\ Correspondence: Leyza Paloschi de Oliveira, Rua Moacir Sampaio, 80, CEP 89.500-070, Caçador, Brazil. Tel: \\ 55-49-999-126-147. E-mail: leyza@uniarp.edu.br
}

Received: January 31, 2021

Accepted: March 11, 2021

Online Published: April 15, 2021

doi:10.5539/jas.v13n5p69

URL: https://doi.org/10.5539/jas.v13n5p69

\begin{abstract}
The production of medicinal plants which have an association with biotrophic fungi requires non-residual and favorable methods to the host with tolerance to the presence of phytopathogens. The objective of this work was to evaluate the effect of homeopathic preparations on the rust severity and the growth of Malva sylvestris plants. M. sylvestris seedlings were prepared in $600 \mathrm{ml}$ containers with commercial substrate. The seedlings were arranged in pots at 26 days of age and outlined in two experiments. The treatments consisted of Amonnium carbonicum (Am. carb.), Atropa belladonna (Bell.), Calcarea carbonica (Calc. carb.), Silicea terra (Sil.) and Sulfur (Sulf.), all at 30CH (centesimal Hahnemannian dilution order). The last two dynamizations (29 and 30CH) were prepared in distilled water for all treatments. Control plants were treated with water. Natural inoculation of the plants with Puccinia malvacearum occurred in the first experiment, and the applications of homeopathic preparations were carried out every seven days for five weeks. Four evaluations of rust severity, diameter, height and number of leaves were conducted. Next, M. sylvestris seedlings were transplanted into pots with 5 liters of substrate in the second experiment and the growth curve of the plant was observed in relation to the diameter and height variables. Am. Carb. reduced $18.29 \%$ of the rust severity in relation to the control plants. Sil. $30 \mathrm{CH}$ contributed to an increase in stem diameter. There was no interference in the plants' height by homeopathic preparations. The application of homeopathies in M. sylvestris can contribute to their production, reducing the rust intensity considered in the crop cycle and can assist in the plant growth without leaving residues which can harm pollinators and hyperparasites.
\end{abstract}

Keywords: high dynamic dilutions, Puccinia malvacearum, homeopathic preparations

\section{Introduction}

Malva spp. species evolutionarily developed in close interaction with the Puccinia malvacearum Bertero ex Mont. biotrophic fungus. This relationship is demonstrated by the increase in the number of cells with mucilage in the area with pustules and the passage of $P$. malvacearum through these cells without hindrance or degeneration (Classen, Amelunxen, \& Blaschek, 2001). The bioactivity of Malva spp. is related to mucilage production (Tomoda et al., 1989; Classen \& Blaschek, 1998). According to Mitchell and Roberts (1973), polysaccharides such as arabitol and trehalose can be stored in leaves infected with P. malvacearum in Althea rosea at pustule sites and trehalose in teliospores, which shows the evolutionary advantages of the intimate host and pathogen relationship.

The supply of $M$. sylvestris leaves and mericarps on the market is restricted by rust symptoms so that they cannot have more than one brown teliospore web of the P. malvacearum fungus per $\mathrm{cm}^{2}$ (Brasil, 2000). On the other hand, in accordance with IN No. 17/2014 of the Ministry of Agriculture and Livestock (MAPA) and the National Policy on medicinal and phytotherapic plants of the Ministry of Health, medicinal plants cannot be handled with pesticides (Brasil, 2014, 2016).

The risk of residues of active ingredients and heavy pesticide metals is related to the concentration of these ingredients in the plant's drying process and alteration of the chemical composition of the plants in processing and extracting the herbal medicine (Carvalho, Costa, \& Carnelossi, 2010). In view of this problem, high dynamized dilutions, or homeopathic preparations, have been studied as an adequate measure in treating medicinal plants, since they do not leave chemical residues in fresh or processed products (Casali et al., 2010).

The choice of using homeopathies in agricultural production is provided for in the Organic Law, however, it is 
not exclusive to these systems (Brasil, 2014). Pulido et al. (2017) demonstrated an increase in broccoli (Brassica oleraceae L. var. itálica) biomass through the use of Sulfur $6 \mathrm{CH}$, Silicia terra $6 \mathrm{CH}$, Carbo vegetalis $30 \mathrm{CH}$ and Sulfur 30CH. Leonel and Barros (2013) reported using homeopathy to manage coffee rust (Hemileia vastatrix), in which they used four leaf sprays with a complex of basic pharmaceutical preparations (Silicea $6 \mathrm{CH}$, Sulfur $6 \mathrm{CH}$, and Arsenicum album $6 \mathrm{CH})$ and isotherapic rust pustules $(30 \mathrm{CH})$ during a period of cultivation (December-may), with a positive effect on stains and defoliation. Homeopathic preparations of propolis, Sulfur and Ferrum sulphuricum applied to tomato plants were effective in reducing the intensity of the Alternaria solani phytoparasite and interfering with tomato (Solanum lycopersicum L.) (sin.: Lycopersicon esculentum Mill.) growth (Toledo, Stangarlim, \& Bonato, 2015). The mode of action of homeopathies in plants is still being investigated, but there are studies where the activation of mechanisms of resistance of plants to diseases has been observed (Carneiro \& Teixeira, 2018).

Keeping in mind that the application of high dynamized dilutions can alter pathological processes established in plants and/or prevent them, the objective of this work was to evaluate the effect of homeopathic preparations on the rust severity and the growth of M. sylvestris plants.

\section{Method}

\subsection{Plant Location and Production}

The study was conducted in semi-controlled conditions (greenhouse) in a residential-urban area in the municipality of Caçador, SC, in the period 2018, with support from the Epagri-Lages Homeopathy and Plant Health Laboratory and the UNIARP-Caçador Phytopathology Laboratory.

Malva seedlings were produced from Malva sylvestris seeds introduced in the garden of the Municipality of Caçador. The seedlings were kept in containers of expanded polystyrene (EPS) pots with $600 \mathrm{~mL}$ of Agrinobre ${ }^{\circledR}$ TMX substrate. The plants were kept until the $26^{\text {th }}$ day in a greenhouse with sprinkler irrigation for 5 minutes, three times a day. The plants were then divided from that date into two experiments: (a) evaluation of the Area Under the Disease Progress Curve (AUDPC) and growth of M. sylvestris; and (b) evaluation of the height and diameter growth curve estimate of $M$. sylvestris.

\subsection{Exp. 1 Evaluation of the Area Under the Disease Progress Curve (AUDPC) and Growth of M. sylvestris}

The plants at 26 days remained in the EPS pots and in the greenhouse with sprinkler irrigation 10 minutes three times a day and were submitted to natural inoculation. The greenhouse was maintained with natural ventilation at the top so that the P. malvacearum spores from the M. sylvestris plants kept outside the greenhouse could be carried by the wind inwards to proceed with natural inoculation, being performed on a day with heavy rain and wind. The sprinkling time increased to 15 minutes and the number of irrigations was changed to four times a day for a period of 24 days. Rust symptoms appeared on the leaves one week after the natural inoculation, and all leaves were evaluated according to grades assigned as follows: grade $0=0 \%$; grade $1 \geq 0<5 \%$; grade $2 \geq 5<15 \%$; grade $3 \geq$ $15<25 \%$; grade $4 \geq 25 \%$. The experimental design was a randomized block with five replications and a double-blind procedure, with the treatments for both the applicator of the preparations and the evaluator of the treatments being unknown. Each repetition consisted of one container.

The weekly treatments started one week after being considered a natural infection by applying the homeopathic preparations of Amonnium carbonicum (Am. Carb.), Atropa belladonna (Bell.), Calcarea carbonica (Calc. Carb.), Silicea terra (Sil.) and Sulfur (Sulf.) in the thirtieth centesimal Hahnemannian dilution (30CH). The choice of homeopathic preparations was made according to the characteristics of plant and rust symptoms, with analogy between the symptoms presented in the homeopathic matter medical. The symptoms used for repertorization were: eruptions, red; eruptions, pustules; thrist, large quantities, for; food and drinks, sugar desire; inflamation; light-desire for. The control was carried out with distilled water. The dynamizations were prepared according to FHB (Brasil, 2011a). The last two dilutions for preparing homeopathies for each potency/treatment were done in distilled water. The adopted homeopathic nomenclature, name and abbreviation were based on that described by Soares (2005). The treatments were applied once a week with $2 \pm 0.2 \mathrm{~mL}$ per plant, so that at least one drop touched each leaf and the rest was applied to the plant's stem for a period of five weeks. Evaluations were performed by measuring the growth in height and diameter by the difference between the first and last evaluation divided by the number of days. The evaluation of the area affected by rust of all leaves was performed weekly by the diagrammatic scale in the period of 4 weeks. Afterwards, the disease severity index per plant, McKinney index (McKinney, 1923), Equation 1 was calculated which was subsequently used to calculate AUDPC (Campbell \& Madden, 1990), using four evaluations for the construction of the curve.

$$
\mathrm{ID}=100 \times \sum_{\mathrm{i}=1}^{\mathrm{k}} \frac{\mathrm{y}_{\mathrm{i}} \cdot \mathrm{f}_{\mathrm{i}}}{\mathrm{n} \cdot \mathrm{y}_{\mathrm{k}}}
$$


where, $y_{i}$ represents the degree of the scale, f represents the number of plants with infection level $y_{i}, n$ represents the number of plants evaluated, and $y_{\mathrm{k}}$ represents the maximum degree of infection.

\subsection{Exp. 2 Evaluation of the Height and Diameter Growth Curve Estimate of M. sylvestris}

Seedlings at 26 days were standardized and transplanted to pots with 5 liters of Agrinobre ${ }^{\circledR}$ TMX substrate, kept in a shelter with a white screen and drip irrigated four times a day for five minutes. After 13 days, the plants received the same homeopathic treatments described above for a total of six applications. Plants were evaluated for diameter and height growth variables at 7, 14, 21, 28, 49 and 56 days after treatments. The experimental design was a randomized block with five replications and double blind, with the repetition being formed by a vase.

\subsection{Statistical Analyses}

Data analyses of the diameter, height and AUDPC variables of the treatments were performed using the classic analysis of variance, with the presupposition of normality being verified through the Shapiro-Wilk test and the homoscedasticity through the Bartlett test. Tukey's contrasts and the procedure for testing linear hypotheses described by Hothorn, Bretz, and Westfall (2008) were used to compare treatment levels.

The number of leaves variable was analyzed using the Poisson model with a superdispersion parameter (quasipoisson) as it is counting, and the deviance analysis was performed using the $\mathrm{F}$ test.

The growth curve for the height and diameter variables of the M. sylvestris treated with Am. Carb., Bell., Calc. carb., Sil., and Sulf. homeopathic preparations and control were adjusted by linear and logistic models, considering the treatments and the different evaluation dates (days) as descriptive variables. The Akaike Information Criterion (AIC) was used for selection among them. The comparison between treatments was performed using the confidence intervals of the parameters of the selected model.

All analyzes were performed using the $\mathrm{R}$ software program (R Core Team, 2017) considering $5 \%$ significance.

\section{Results and Discussion}

The use of Am. Carb in the $30 \mathrm{CH}$ provided a reduction of $18.29 \%$ in the AUDPC of rust compared to the control (Table 1).

Table 1. Area Under Disease Progress Curve and Malva sylvestris growth treated with homeopathic preparations, Caçador-SC, Brazil, 2018

\begin{tabular}{lllll}
\hline Treatments & AUDPC & Diameter $\left(\mathrm{mm} \mathrm{d}^{-1}\right)$ & Height $\left(\mathrm{cm} \mathrm{d}^{-1}\right)$ & Leaves $\left(\mathrm{n}^{\mathrm{o}}.\right)$ \\
\hline Sulfur $30 \mathrm{CH}$ & $871.50 \pm 25.69 \mathrm{c}$ & $0.10 \pm 0.02 \mathrm{n}^{\mathrm{ns}}$ & $0.52 \pm 0.04^{\mathrm{ns}}$ & $4.8 \pm 0.66^{\mathrm{ns}}$ \\
Calcarea carbonica $30 \mathrm{CH}$ & $805.00 \pm 23.49 \mathrm{bc}$ & $0.08 \pm 0.02$ & $0.46 \pm 0.03$ & $4.6 \pm 0.25$ \\
Control & $818.13 \pm 11.42 \mathrm{bc}$ & $0.09 \pm 0.01$ & $0.48 \pm 0.05$ & $4.6 \pm 0.24$ \\
Silicea $30 \mathrm{CH}$ & $780.50 \pm 33.28 \mathrm{~b}$ & $0.09 \pm 0.02$ & $0.46 \pm 0.06$ & $4.2 \pm 0.37$ \\
Atropa Belladonna $30 \mathrm{CH}$ & $759.50 \pm 14.06 \mathrm{~b}$ & $0.10 \pm 0.02$ & $0.54 \pm 0.03$ & $4.6 \pm 0.25$ \\
Amonnium carbonicum $30 \mathrm{CH}$ & $668.50 \pm 14.00 \mathrm{a}$ & $0.09 \pm 0.01$ & $0.44 \pm 0.03$ & $4.2 \pm 0.37$
\end{tabular}

Note. AUDPC: Area Under Disease Progress Curve; 30CH: centesimal Hahnemannian dilution order; Averages followed by the same letter in the column do not differ significantly from each other, considering the Tukey test $(\mathrm{p} \leq 0.05)$; ns: there was no significant effect of the treatments $(\mathrm{p} \leq 0.05)$; Control: water; data from four evaluations, 28-day period.

Am. carb is associated with rust symptoms on the leaves, as in the case of Bell., by analogy to the presence of dark red spore mass. According to Tyler (1992), Calc. carb. is Bell's chronic state and may also present weakness, late development and worsens in cold and wet weather (Tyler, 1992; Vannier \& Poirier, 1987). By analogy to medical matter, Am. Carb. is indicated in cases of weakness when skin rashes worsen due to wet and rainy weather. It is a suitable remedy for the female organism, fainting, vertigo and considered antipsoric by Hahnemann (Hahnemann, 2018; Tyler, 1992). Therefore, there was a certain similarity correspondence in $M$. sylvestris with the difficulty of the plant to remain upright many times, marked weakness after flowering and fruiting, with signs of $P$. malvacearum on the leaves resembling eruptions, with humid and rainy weather favoring infection, and showy flowers with feminine characteristics.

Plants treated with Sulfur showed higher mean AUDPC values when compared to the average values obtained for Am. Carb., Sil. and Bel., but did not differ from the values observed for Calc. carb and the control. The rust 
AUDPC was $23.82 \%$ lower when using Am. Carb than when using Sulfur. The responses in the body in relation to applying homeopathies are dependent on the vital force of individuals and the similarity between the symptoms generated by homeopathy and those presented by the individual (Hahnemann, 2013). There is a report on the efficiency of Sil 30CH application in grape buds for rust control, observing the occurrence of $7 \%$ severity in the treated ones, while there was $100 \%$ severity in the buds in the water control treatment (Souza, Collet, \& Bonato, 2005). The use of Sil. $12 \mathrm{CH}$ in high humidity conditions favorable to chrysanthemum mortality provided $100 \%$ plant survival, while $82 \%$ of them withered and died in the control treatment (Singhania \& Singhania, 2014).

M. sylvestris growth in experiment 2 was affected by the homeopathic application. Table 2 shows that the confidence interval asymptote of the logistic model for the diameter of plants treated with Sil. was from 14.77 $\mathrm{mm}$ to $15.94 \mathrm{~mm}$, and differs from the range of control plants which are in $13.18 \mathrm{~mm}$ to $14.65 \mathrm{~mm}$. The Sulf., Calc-carb., Am. Carb. and Bel. homeopathies did not differ from the control, as the confidence intervals for the parameters overlap (Table 2).

Table 2. Estimates of the confidence intervals of the logistic model parameters adjusted according to homeopathy treatments for the diameter variable. Caçador, SC, Brazil, 2018

\begin{tabular}{|c|c|c|c|c|c|c|}
\hline \multirow{3}{*}{ Treatments } & \multirow{2}{*}{\multicolumn{2}{|c|}{$\begin{array}{c}\text { Asymptote } \\
\text { Limit }(\mathrm{mm})\end{array}$}} & \multirow{2}{*}{\multicolumn{2}{|c|}{$\begin{array}{c}\mathrm{x} \text { median } \\
\text { Limit }(\mathrm{cm})\end{array}$}} & \multirow{2}{*}{\multicolumn{2}{|c|}{$\frac{\text { Scale }}{\text { Limit }(\mathrm{cm})}$}} \\
\hline & & & & & & \\
\hline & Lower & Upper & Lower & Upper & Lower & Upper \\
\hline Sulfur $30 \mathrm{CH}$ & 14.30 & 16.19 & 5.71 & 10.70 & 6.42 & 13.36 \\
\hline Calcarea carbonica $30 \mathrm{CH}$ & 14.09 & 15.10 & 6.24 & 8.96 & 6.19 & 9.63 \\
\hline Control & 13.18 & 14.65 & 5.67 & 9.92 & 5.79 & 11.30 \\
\hline Silicea $30 \mathrm{CH}$ & 14.77 & 15.94 & 5.56 & 8.83 & 7.36 & 11.79 \\
\hline Atropa belladonna $30 \mathrm{CH}$ & 14.44 & 15.62 & 6.95 & 9.97 & 6.59 & 10.50 \\
\hline Amonnium carbonicum $30 \mathrm{CH}$ & 13.92 & 15.41 & 6.50 & 10.35 & 5.69 & 10.59 \\
\hline
\end{tabular}

It can be seen in Figure 1 that the estimate of the Sil diameter curve is superior to that of the control plants. The diameter of the other treatments (Sulf., Calc. Carb., Bell. And Am. Carb.) is represented in the intermediate curve between the control and Sil., but there is no difference between them and the control.

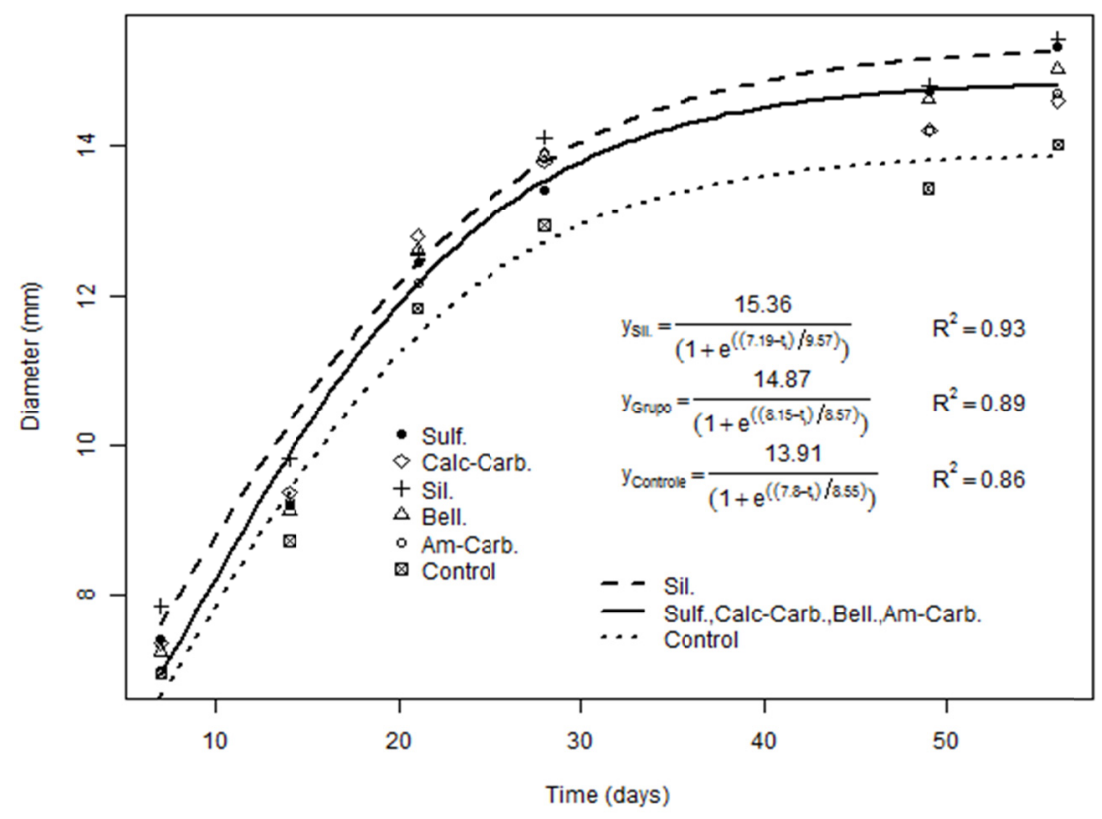

Figure 1. Estimates logistic model according to homeopathy treatments for the diameter variable.

Caçador, SC, Brazil, 2018 
Signs of weakness are reported in Sil's medical material, which is not due to deficient nutrition, but to deficient assimilation, which is influenced by the moon, worsening in the new and full moon (Tyler, 1992). The better assimilation of nutrients and water capture may explain the increase in diameter observed when Sil was applied. The influence of treatments with homeopathic preparations on plant growth and protection has been reported by Swarowsky et al. (2014) using Cina in managing Meloidogyne incognita, without nematostatic and nematicidal effect. In the case of $M$. sylvestris and P. malvacearum association, the best assimilation of nutrients can assist in mucilage production and plant survival.

The homeopathic applications did not affect plant height. In this case, there was an overlapping of the intervals of all the logistic model parameters between treatments (Table 3 ).

Table 3. Estimates of the confidence intervals of the logistic model of homeopathy treatments for the height parameter. Caçador, SC, Brazil, 2018

\begin{tabular}{|c|c|c|c|c|c|c|}
\hline \multirow{3}{*}{ Treatments } & \multirow{2}{*}{\multicolumn{2}{|c|}{$\begin{array}{c}\text { Asymptote } \\
\text { Limit (mm) }\end{array}$}} & \multirow{2}{*}{\multicolumn{2}{|c|}{$\begin{array}{c}\mathrm{x} \text { median } \\
\text { Limit }(\mathrm{cm})\end{array}$}} & \multirow{2}{*}{\multicolumn{2}{|c|}{$\frac{\text { Scale }}{\text { Limit }(\mathrm{cm})}$}} \\
\hline & & & & & & \\
\hline & Lower & Upper & Lower & Upper & Lower & Upper \\
\hline Sulfur $30 \mathrm{CH}$ & 14.30 & 16.19 & 5.71 & 10.70 & 6.42 & 13.36 \\
\hline Calcarea carbonica $30 \mathrm{CH}$ & 14.09 & 15.10 & 6.24 & 8.96 & 6.19 & 9.63 \\
\hline Control & 13.18 & 14.65 & 5.67 & 9.92 & 5.79 & 11.30 \\
\hline Silicea $30 \mathrm{CH}$ & 14.77 & 15.94 & 5.56 & 8.83 & 7.36 & 11.79 \\
\hline Atropa belladonna $30 \mathrm{CH}$ & 14.44 & 15.62 & 6.95 & 9.97 & 6.59 & 10.50 \\
\hline Amonnium carbonicum $30 \mathrm{CH}$ & 13.92 & 15.41 & 6.50 & 10.35 & 5.69 & 10.59 \\
\hline
\end{tabular}

Figure 2 shows the general growth curve for the height of $M$. sylvestris. Excessive height growth of $M$. sylvestris can favor the plant tipping. The plants were at the beginning of flowering and slowing the growth rate at 56 days after the first treatment, corresponding to 95 days since sowing.

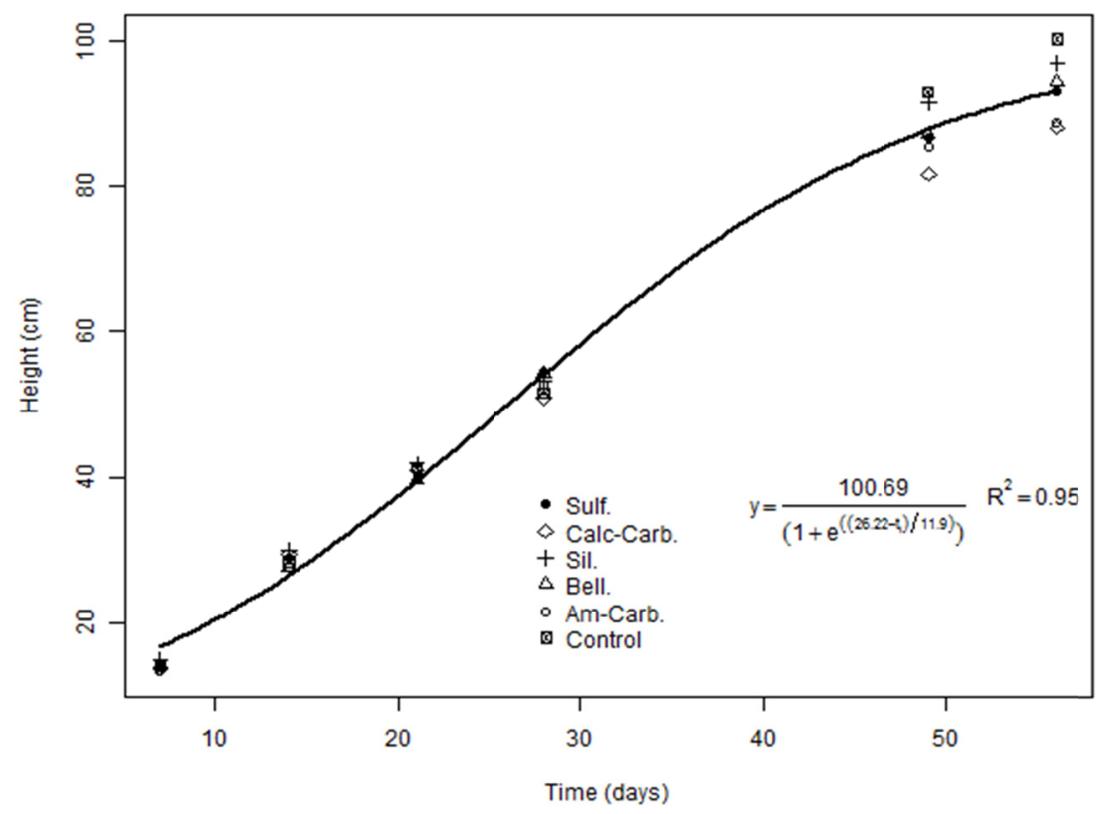

Figure 2. Estimation of the cumulative height growth curve from the data means adjusted to the logistic model

\section{Conclusion}

It was observed that Ammonium carbonic was effective in reducing $18.29 \%$ of the rust severity expressed by the AUDPC in relation to the control with water. In comparing Am. Carb. with the other tested homeopathic treatments, it was observed that the AUDPC was $23.82 \%$ lower than that of Sulf. and differed from the others. $M$. 
sylvestris growth was affected by the use of Sil. $30 \mathrm{CH}$ due to the increase in diameter compared to the control with water.

Am. Carb $30 \mathrm{CH}$ is recommended for managing the Malva sylvestris and Puccinia malvacearum interaction. Considering that the plant's resistance is overcome as the fungus develops specialized structures in the host forming a matrix of nutrient exchange, the use of Sil. $30 \mathrm{CH}$ can assist in assimilating nutrients and favor plant growth.

\section{Acknowledgements}

To FAPESC through the Rede Guarani Serra Geral/TO 2015TR1067 project, CNPq (process n. 304018/2015; 307376/2017-6) and to Programa UNIEDU de Pós-graduação for the scholarship granted to the first author.

\section{References}

Brasil, Ministério da Agricultura, Pecuária e do Abastecimento. (2014). Altera Instrução Normativa $n^{\circ} 46$, de 6 de outubro de 2011 que estabelece o regulamento técnico para os sistemas orgânicos de produção animal e vegetal, bem como as listas de substâncias permitidas para uso nos sistemas orgânicos de produção animal e vegetal (Instrução Normativa $n^{\circ} 17$, de 18 de Junho de 2014). Diário Oficial [da] República Federativa do Brasil (Section 1, pp. 32-36). Poder Executivo, Brasília, DF.

Brasil, Ministério da Saúde. (2016). Política e Programa Nacional de Plantas Medicinais e Fitoterápicos. Ministério da Saúde, Secretaria de Ciência, Tecnologia e Insumos Estratégicos, Departamento de Assistência Farmacêutica, Brasília.

Brasil. (2000). Farmacopeia Brasileira (4th ed.). São Paulo, SP: Atheneu Editora.

Campbell, C. L., \& Madden, L. V. (1990). Introduction to plant disease epidemiology. New York, NY: Wiley-Interscience Publication.

Carneiro, S. M. T. P. G., \& Teixeira, M. Z. (2018). Homeopatia e controle de doenças de plantas e seus patógenos. Scientia Agraria, 17(3), 250-262. Retrieved from http://e-revista.unioeste.br/index.php/scientiaagraria/ article/view/17994/13430

Carvalho, L. M., Costa, J. A. M. da, \& Carnelossi, A. G. (2010). Qualidade em plantas medicinais. Embrapa Tabuleiros Costeiros, Aracajú, SE. Retrieved from http://www.cpatc.embrapa.br/publicacoes_2010/ doc_162.pdf

Casali, V. W. D., Castro, D. M., Armond, C., Fonseca, M. C. M., Andrade, F. M. C. de, Duarte, E. S. M., \& Arruda, V. M. (2010). Benefícios da homeopatia no cultivo de plantas medicinais. Informe Agropecuário, Belo Horizonte, 31(255), 79-84. Retrieved from http:/www.epamig.br/download/informe-agropecuario-25 5-plantas-medicinais-e-aromaticas-2010

Classen, B., \& Blaschek, W. (1998). High molecular weight acidic Polysaccharides from Malva sylvestris and Alcea rosea. Planta Medica, 64, 640-644. https://doi.org/10.1055/s-2006-957538

Classen, B., Amelunxen, F., \& Blaschek, W. (2001). Ultrastructural observations on the rust fungus Puccinia malvacearum in Malva sylvestris ssp. Mauritiana. Plant Biology, 3, 437-442. https://oi.org/10.1055/ s-2001-16456

Hahnemann, S. (2013). Exposição da Doutrina Homeopática, ou, Organon da Arte de Curar (5th ed.). São Paulo, SP: GEHSP "Benoit Mure”.

Hahnemann, S. (2018). Doenças crônicas: Matéria medicas dos medicamentos antipsóricos. Tradução Tarcísio Freitas Bazílio. Retrieved from https://bentomure.com.br/_files/200000094-e4bbce5b68/medicamentos_anti psoricos.pdf

Leonel, A. H., \& Barros, B. H. R. (2013). Utilização de preparados homeopáticos para controle da ferrugem do café (Hemileia vastatrix) na região da Alta Mogiana. Caderno de Agroecologia. Congresso Brasileiro de Agroecologia, 8, Porto Alegre, Brasil.

McKinney H. H. (1923). Influence of soil, temperature and moisture on infection of wheat seedlings by Helminthosporium sativum. Journal of Agricultural Research, 26, 195-217.

Mitchell, D. T., \& Roberts, S. M. (1973). Carbohydrate composition of tissues infected by the autoecious rusts, Puccinia pelargonii-zonalis and P. malvacearum. Physyological Plant Pathology, 3, 481-488. https://doi.org/10.1016/0048-4059(73)90058-1 
Pulido, E., Boff, P., Duarte, T., \& Boff, M. I. (2017). High dilution preparations for organic production system of broccoli. Agronomía Colombiana, 35, 53-58. https://doi.org/10.15446/agron.colomb.v35n1.58586

R Core Team. (2017). R: A language and environment for statistical computing. R Foundation for Statistical Computing, Vienna, Austria. Retrieved from https://www.R-project.org

Singhania, P. K., \& Singhania, A. (2014). Homoepathy in agriculture. In G. Rahmann \& U. Aksoy (Eds.), Proceedings of the 4th ISOFAR Scientific Conference. Building Organic Bridges at the Organic World Congress, 4, Istanbul, Turkey. Retrieved from https://orgprints.org/23727/1/23727_MM.pdf

Souza, A. F., Collet, M. A., \& Bonato, C. M. (2005). Efeito de soluções homeopáticas no controle da ferrugem (Phakopsora euvitis) em Videira. Arquivos da Apadec, 9(2), 27-30. Retrieved from http://periodicos.uem.br/ ojs/index.php/ArqMudi/article/view/20684

Swarowsky, R. A., Kunh, O. J., \& Estevez, R. L. (2014). Influence of high dilutions of cina for the control of Meloidogyne incognita in tomato plants. American Journal of Plant Sciences, 5, 3695-3701. https://doi.org/ 10.4236/ajps.2014.525385

Toledo, M. V., Stangarlin, J. R., \& Bonato, C. M. (2015). Controle da pinta preta e efeito sobre variáveis de crescimento em tomateiro por preparados homeopáticos. Summa Phytopathologica, 41, $126-132$. https://doi.org/10.1590/0100-5405/1944

Tomoda, M., Gonda R., Shimizu, N., \& Yamada, H. (1989). Plant. Mucilages. XLII. An anti-complentary mucilage from leaves of Malva sylvestris var. mauritiana. Chemical and Pharmaceutical Bulletin, 37, 3029-3032. https://doi.org/10.1248/cpb.37.3029

Tyler, M. L. (1992). Retratos de medicamentos homeopáticos. São Paulo, SP: Editora Santos.

Vannier, L., \& Poirier, J. (1987). Tratado de matéria médica homeopática (9th ed.). São Paulo, SP: Andrei.

\section{Copyrights}

Copyright for this article is retained by the author(s), with first publication rights granted to the journal.

This is an open-access article distributed under the terms and conditions of the Creative Commons Attribution license (http://creativecommons.org/licenses/by/4.0/). 